\title{
Comparison of the Effects of Various Inducers on 7-Alkoxycoumarin O-Dealkylase Activities in Liver Microsomes
}

\author{
Hiroyasu OKUNO, Sadao NAKANISHI, Yuko KITAO, Masashi TAKASU, \\ Toshihiko MURASE, Yasuko SHIOZAKI and Yoshiko SAMESHIMA \\ Third Department of Internal Medicine. Kansai Medical University, \\ Fumizono-cho, Moriguchi, Osaka 570, Japan \\ Accepted January 19, 1989
}

\begin{abstract}
The effects of six inducers and malotilate on 7-alkoxycoumarin $\mathrm{O}$ dealkylase activities in rat liver microsomes were examined. Phenobarbital (PB) $(100 \mathrm{mg} / \mathrm{kg})$ was administered intraperitoneally to rats for 6 days; 3 -methylcholanthrene (3-MC) $(40 \mathrm{mg} / \mathrm{kg}), \beta$-naphthoflavone $(\beta-N F)(40 \mathrm{mg} / \mathrm{kg})$, isosafrole $(150$ $\mathrm{mg} / \mathrm{kg})$ and polychlorinated biphenyls (PCB) $(100 \mathrm{mg} / \mathrm{kg})$ were administered intraperitoneally for 3 days; isoniazid $(\mathrm{INH})(50 \mathrm{mg} / \mathrm{kg})$ was administered intraperitoneally for 10 days; and malotilate $(500 \mathrm{mg} / \mathrm{kg})$ was administered orally for 3 days. The $\mathrm{O}$-dealkylase activities toward 7-methoxycoumarin (7-MC), 7 ethoxycoumarin (7-EC) and 7-propoxycoumarin (7-PC) were examined $24 \mathrm{hr}$ after the final administration of the drugs. The ratios of 7-EC O-deethylase and 7 $\mathrm{PC} \mathrm{O}$-depropylase to 7-MC O-demethylase activity in the control and six inducertreated groups were compared. The ratios in the groups treated with the six compounds, each of which induces a different form(s) of cytochrome P-450 (P-450), were clearly different from each other. Therefore, the measurement of 7 -alkoxycoumarin $\mathrm{O}$-dealkylase activities should be extremely useful for the routine determination of the molecular species of P-450. On the other hand, the ratio in the malotilate-treated group was different from that in any other inducer-treated group. so that there might be a possibility that malotilate induced a form (s) of P-450 that is different from any of the already known species.
\end{abstract}

Many hydrophobic compounds, including drugs, chemicals, environmental pollutants and carcinogens, are biotransformed into more hydrophilic metabolites through the mixed-function oxidase system in liver microsomes, in which cytochrome P-450 (P-450) plays an important role as a key enzyme (1)

It has been recognized that $P-450$ consists of multiple species and that various compounds induce a different form(s) of P-450. each of which has a characteristic substrate specificity to some extent $(2,3)$. Levin et al. (4-9) have systematically purified various forms of P-450 from rats, which have been designated as P-450a-ij.

Recently, the measurement of 7 -alkoxycoumarin 0 -dealkylase activities (7-methoxycoumarin (7-MC) O-demethylation, 7ethoxycoumarin (7-EC) O-deethylation, 7- propoxycoumarin (7-PC) O-depropylation and 7-butoxycoumarin (7-BC) O-debutylation) has been reported to be useful for investigating the molecular multiplicity of P-450. Matsubara et al. (10) demonstrated that all these $\mathrm{O}$-dealkylase activities in rat liver microsomes were stimulated by the treatment of animals with phenobarbital (PB): in contrast, treatment with 3-methylcholanthrene $(3-M C)$ or $\beta$-naphthoflavone $(\beta-N F)$ markedly increased 7-EC O-deethylase, 7. PC O-depropylase and 7-BC O-debutylase activities, but not 7-MC O-demethylase activity. Kasahara et al. (11) investigated the effects of D-galactosamine and carbon tetrachloride $\left(\mathrm{CCl}_{4}\right)$ on 7-alkoxycoumarin $\mathrm{O}$ dealkylase activities in rat liver microsomes They reported that the ratio of 7 -EC $\mathrm{O}$ deethylase and 7-PC O-depropylase to 7- 
MC O-demethylase activity was not altered by the D-galactosamine treatment, but decreased by the $\mathrm{CCl}_{4}$ treatment, although all these $\mathrm{O}$-dealkylase activities were reduced by either pretreatment. They both emphasized that the measurement of 7-alkoxycoumarin $\mathrm{O}$ dealkylase activities was applicable for the routine determination of the molecular species of P-450. Kamataki et al. (12) referred to the effects of isosafrole and spironolactone in their report concerning sex differences in 7 . alkoxycoumarin $\mathrm{O}$-dealkylase activities. However, there are no reports, to our knowledge, concerning the effect of any other inducer on 7-alkoxycoumarin O-dealkylase activities.

In the present study. we examined the effects of six inducers, PB, 3-MC, $\beta-N F$. isosafrole, polychlorinated biphenyls (PCB) and isoniazid (INH), each of which induces a different form(s) of P-450 (2,3), on 7alkoxycoumarin $\mathrm{O}$-dealkylase activities and compared them with each other. We also measured these $\mathrm{O}$-dealkylase activities in rats treated with malotilate, a new type of inducer $(13,14)$, and compared them with those in the groups treated with the other six induces.

\section{Materials and Methods}

Animals and treatments: Male SpragueDawley rats, each weighing $200 \mathrm{~g}$, were maintained on a standard pellet diet and water ad libitum. PB was dissolved in saline and administered intraperitoneally to the rats at a dose of $100 \mathrm{mg} / \mathrm{kg}$. once a day for 6 days. 3-MC, $\beta$-NF, isosafrole and PCB were dissolved in olive oil and administered intraperitoneally for 3 days at a dose of $40 \mathrm{mg} /$ $\mathrm{kg}, 40 \mathrm{mg} / \mathrm{kg}, 150 \mathrm{mg} / \mathrm{kg}$ and $100 \mathrm{mg} / \mathrm{kg}$. respectively. INH was diluted with saline and administered intraperitoneally at a dose of 50 $\mathrm{mg} / \mathrm{kg}$ for 10 days. Malotilate was dissolved in olive oil and administered orally at a dose of $500 \mathrm{mg} / \mathrm{kg}$ for 3 days. The animals were sacrificed $24 \mathrm{hr}$ after the final administration of the drugs. Untreated rats were used as the control. They were fasted $18 \mathrm{hr}$ prior to killing, but had free access to tap water.

Preparation of microsomes: Rat liver microsomes were prepared as follows: Excised livers were thoroughly perfused with cold $0.15 \mathrm{M} \mathrm{KCl}$ and homogenized in 4 -fold volumes of $0.15 \mathrm{M} \mathrm{KCl}$ solution containing $10 \mathrm{mM}$ EDTA using a Potter-type Teflon glass homogenizer. The homogenate was centrifuged at $10,000 \times \mathrm{g}$ for $15 \mathrm{~min}$ in a refrigerated centrifuge (Kubota, KR/20000). The supernatant was then centrifuged at $105,000 \times \mathrm{g}$ for $60 \mathrm{~min}$ in a preparative ultracentrifuge (Hitachi, 70P-72). The pellet of microsomes was suspended in the homogenating solution in the homogenizer and centrifuged again as described above. The resulting pellet was suspended in $20 \mathrm{mM}$ potassium phosphate buffer ( $\mathrm{pH}$ 7.4) containing $15 \%$ glycerol. These operations were performed at $0-4{ }^{\circ} \mathrm{C}$.

Assays of drug metabolizing activity: The content of P-450 was measured by the method of Omura and Sato (15). The content of cytochrome $b_{5}\left(b_{5}\right)$ and the activity of NADPH-cytochrome $c$ reductase were assayed by the method of Omura and Takesue (16). The microsomal protein content was measured by the method of Lowry et al. (17).

The $\mathrm{O}$-dealkylase activities toward 7-MC, 7-EC and 7-PC were determined by a direct fluorometric measurement of 7-hydroxycoumarin produced according to the method of Ullrich and Weber (18). The substrates, 7-MC, 7-EC and 7-PC, were dissolved in 1 $\mathrm{M}$ Tris- $\mathrm{HCl}$ buffer $(\mathrm{pH} 7.6)$ to give $10^{-3} \mathrm{M}$ solutions. The incubation mixture consisted of microsomes, $10^{-4} \mathrm{M}$ substrate and $10^{-4} \mathrm{M}$ $\mathrm{NADPH}$ in $1.0 \mathrm{ml}$ of $0.1 \mathrm{M}$ Tris- $\mathrm{HCl}$ buffer $(\mathrm{pH}$ 7.6). The reaction was started by adding NADPH $\left(10 \mu l, 10^{-2} \mathrm{M}\right)$, and the mixture was incubated aerobically at $37^{\circ} \mathrm{C}$. The increase in the fluorescence intensity with time was measured at $460 \mathrm{~nm}$ with an excitation of $372 \mathrm{~nm}$ using a fluorescence spectrophotometer (Hitachi, 650-60).

Chemicals: The drugs used were as follows: PB (Tokyo Kasei Kogyo Co.. Tokyo), $3-M C$ and $\beta-N F$ (Sigma Chemical Co., St. Louis, MO, U.S.A.), isosafrole (Nakarai Chemicais, Kyoto), PCB (Kanechlor KC500. Gasukuro Kogyo Co., Tokyo), INH (Iscotin (Inj.), Daiichi Pharmaceutical Co., Tokyo). Malotilate was a generous gift from Daiichi Pharmaceutical Co., Tokyo. 7-EC and 7-MC were purchased from Nakarai Chemicals (Kyoto) and Aldrich Chemical Co. 
(Milwaukee, WI, U.S.A.), respectively. 7-PC was synthesized at Sorl Laboratory (Aoyamacho, Mie, Japan).

Statistical analysis: Significance of difference was determined by Student's $t$-test for unpaired variables.

\section{Results}

Contents of P-450 and $b_{5}$ and the activity of NADPH-cytochrome $c$ reductase in rats treated with various inducers: The effects of the six inducers and malotilate on the contents of $\mathrm{P}-450$ and $b_{5}$ and the activity of NADPH-cytochrome $c$ reductase $(/ \mathrm{mg}$ microsomal protein) are shown in Table 1.

The P-450 content was noticeably increased to $155-205 \%$ of the control level in the PB-, 3-MC-, $\beta$-NF-, isosafrole- and PCBtreated groups. In contrast, it was decreased to $73.2 \%$ of the control level $(P<0.01)$ by the malotilate treatment and not significantly affected by the INH treatment. The $b_{5}$ content was noticeably increased to $163-233 \%$ of the control level in every inducer-treated group and the malotilate-treated group. The activity of NADPH-cytochrome $c$ reductase was enhanced by the PB, isosafrole and malotilate treatments to 160,267 and $192 \%$ of the control level, respectively. In contrast, the treatments with 3-MC, $\beta-N F, P C B$ and INH did not significantly affect the activity of NADPH-cytochrome $c$ reductase.

O-Dealkylase activities toward 7-MC, 7 $E C$ and $7-P C$ in rats treated with various inducers: The effects of the six inducers and malotilate on the $\mathrm{O}$-dealkylase activities toward 7-MC, 7-EC and 7-PC (/nmol P450) are shown in Figs. 1, 2 and 3, respectively. The ratio of 7 -EC $\mathrm{O}$-deethylase and 7-PC O-depropylase to 7-MC O-demethylase activity in each group is shown in Table 2 .

The ratio of 7-EC O-deethylase and 7-PC O-depropylase to 7-MC O-demethylase activity in the control group was 1.00:1.08:0.13. In the PB-treated group, the O-dealkylase activities toward 7-MC, 7-EC and 7-PC were significantly increased to $242 \%, 304 \%$ and $867 \%$ of the control leve!, respectively, and

Table 1. The effects of six inducers and malotilate on the contents of cytochromes P-450 and $b_{5}$ and the activity of NADPH-cytochrome $c$ reductase

\begin{tabular}{|c|c|c|c|}
\hline & $\begin{array}{c}\text { P-450 } \\
\text { (nmol/mg MS prot.) }\end{array}$ & $\stackrel{b_{5}}{(\mathrm{nmol} / \mathrm{mg} \mathrm{MS} \text { prot.) }}$ & $\begin{array}{l}\text { NADPH-cyt. c reductase } \\
\text { (nmol/mg MS prot./min) }\end{array}$ \\
\hline $\begin{array}{l}\text { Control } \\
\qquad(n=6)\end{array}$ & $\begin{array}{l}1.12 \pm 0.11 \\
(100 \%)\end{array}$ & $\begin{array}{l}0.27 \pm 0.04 \\
(100 \%)\end{array}$ & $\begin{array}{c}102.12 \pm 17.18 \\
(100 \%)\end{array}$ \\
\hline $\begin{array}{l}\text { PB } \\
\qquad(n=6)\end{array}$ & $\begin{array}{l}2.10 \pm 0.32^{*} \\
(188 \%)\end{array}$ & $\begin{array}{l}0.49 \pm 0.04^{*} \\
(181 \%)\end{array}$ & $\begin{array}{c}163.22 \pm 8.22^{*} \\
(160 \%)\end{array}$ \\
\hline $\begin{array}{l}3-M C \\
\quad(n=6)\end{array}$ & $\begin{array}{l}1.74 \pm 0.14^{*} \\
(155 \%)\end{array}$ & $\begin{array}{l}0.47 \pm 0.04^{*} \\
(174 \%)\end{array}$ & $\begin{array}{l}88.25 \pm 7.22 \\
\quad(86.4 \%)\end{array}$ \\
\hline $\begin{array}{l}\beta-N F \\
\quad(n=5)\end{array}$ & $\begin{array}{l}2.11 \pm 0.21^{*} \\
\quad(188 \%)\end{array}$ & $\begin{array}{l}0.53 \pm 0.04^{*} \\
(196 \%)\end{array}$ & $\begin{array}{c}90.99 \pm 10.96 \\
(89.1 \%)\end{array}$ \\
\hline $\begin{array}{l}\text { Isosafrole } \\
\qquad(n=7)\end{array}$ & $\begin{array}{l}1.79 \pm 0.10^{*} \\
(160 \%)\end{array}$ & $\begin{array}{l}0.63 \pm 0.05^{*} \\
(233 \%)\end{array}$ & $\begin{array}{c}273.13 \pm 14.79^{*} \\
(267 \%)\end{array}$ \\
\hline $\begin{array}{l}\mathrm{PCB} \\
\qquad(n=6)\end{array}$ & $\begin{array}{l}2.30 \pm 0.13^{*} \\
(205 \%)\end{array}$ & $\begin{array}{l}0.58 \pm 0.03^{*} \\
(215 \%)\end{array}$ & $\begin{array}{c}112.64 \pm 12.43 \\
(110 \%)\end{array}$ \\
\hline $\begin{array}{l}\text { INH } \\
\qquad(n=6)\end{array}$ & $\begin{array}{c}1.01 \pm 0.16 \\
(90.2 \%)\end{array}$ & $\begin{array}{c}0.44 \pm 0.06^{*} \\
(163 \%)\end{array}$ & $\begin{array}{c}104.44 \pm 18.56 \\
(102 \%)\end{array}$ \\
\hline $\begin{array}{l}\text { Malotilate } \\
\quad(n-6)\end{array}$ & $\begin{array}{l}0.82 \pm 0.10^{*} \\
(73.2 \%)\end{array}$ & $\begin{array}{c}0.50 \pm 0.05^{*} \\
(185 \%)\end{array}$ & $\begin{array}{c}195.83 \pm 32.78^{*} \\
(192 \%)\end{array}$ \\
\hline
\end{tabular}

The drugs administered were as follows: phenobarbital (PB), $100 \mathrm{mg} / \mathrm{kg}$, i.p., for 6 days; 3 -methylcholanthrene (3-MC), $40 \mathrm{mg} / \mathrm{kg}$, i.p., for 3 days: $\beta$-naphthoflavone $(\beta-N F), 40 \mathrm{mg} / \mathrm{kg}$, i.p. for 3 days; isosafrole. $150 \mathrm{mg} / \mathrm{kg}$, i.p., for 3 days; polychlorinated biphenyls (PCB), $100 \mathrm{mg} / \mathrm{kg}$, i.p., for 3 days; isoniazid (INH). $50 \mathrm{mg} / \mathrm{kg}$, i.p., for 10 days: malotilate, $500 \mathrm{mg} / \mathrm{kg}$, p.o., for 3 days. Liver microsomes were prepared for the assays $24 \mathrm{hr}$ after the final administration of the drugs. Each value represents the mean \pm S.D. "Significantly different from the control $(P<0.01)$. 


\section{7-MC}

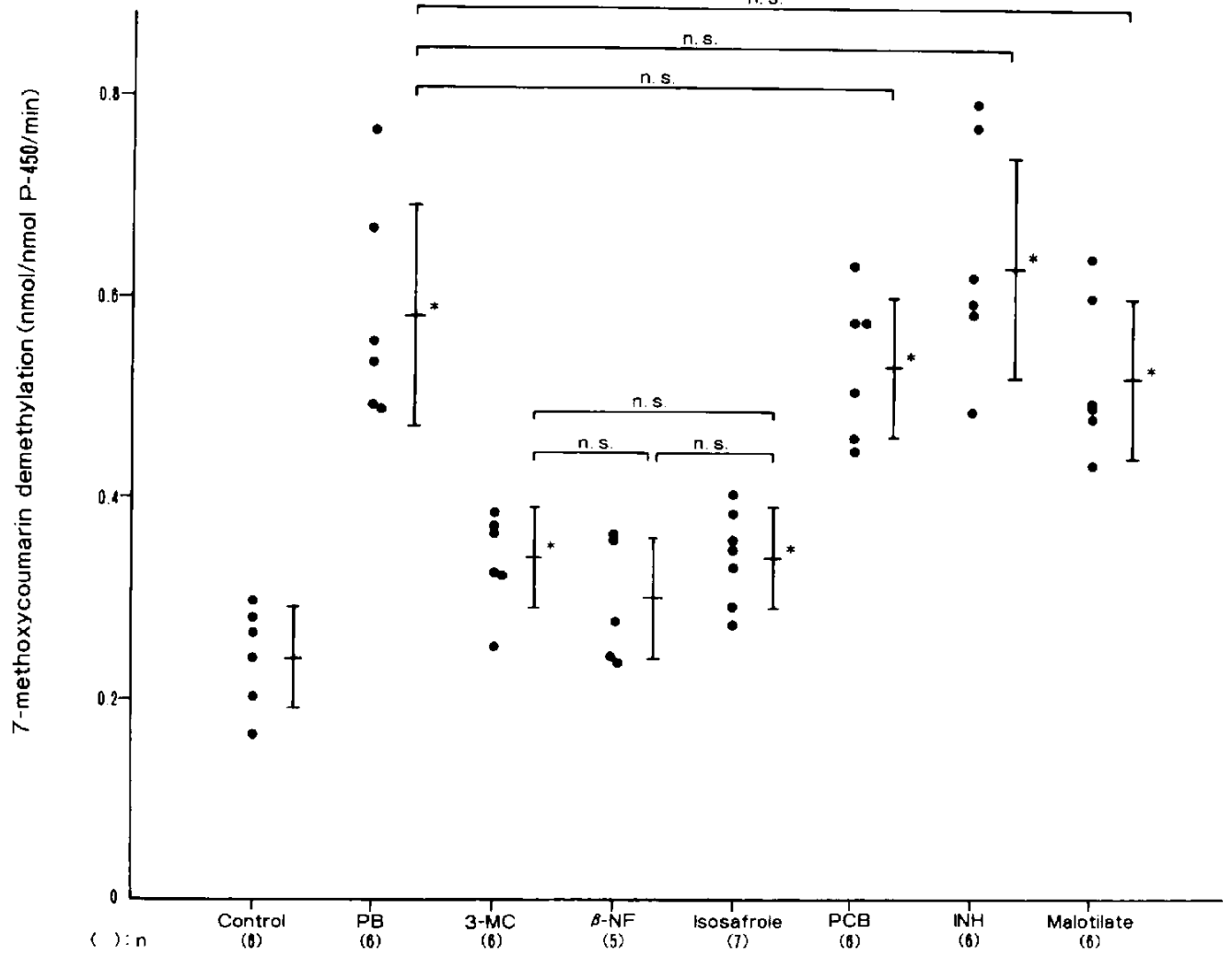

Fig. 1. The effects of phenobarbital (PB), 3-methylcholanthrene (3-MC). $\beta$-naphthoflavone $(\beta-N F)$. isosafrole, polychlorinated biphenyls (PCB), isoniazid (INH) and malotilate on 7-methoxycoumarin (7MC) O-demethylase activity. Each drug was administered as follows: PB, $100 \mathrm{mg} / \mathrm{kg}$, i.p. for 6 days; 3-MC, $40 \mathrm{mg} / \mathrm{kg}$. i.p. for 3 days: $\beta$-NF, $40 \mathrm{mg} / \mathrm{kg}$. i.p. for 3 days; isosafrole, $150 \mathrm{mg} / \mathrm{kg}$, i.p. for 3 days; PCB, $100 \mathrm{mg} / \mathrm{kg}$. i.p., for 3 days; INH. $50 \mathrm{mg} / \mathrm{kg}$. i.p., for 10 days; malotilate, $500 \mathrm{mg} / \mathrm{kg}$, p.o., for 3 days. Liver microsomes were prepared for the assays $24 \mathrm{hr}$ after the final administration of the drugs. Vertical bars represent the mean \pm S.D. *Significantly different from the control $(P<0.01)$.

the ratio of the three $\mathrm{O}$-dealkylase activities was 1.00:1.36:0.45.

By the 3-MC treatment, 7-EC O-deethylase and 7-PC O-depropylase activities were markedly enhanced to $1520 \%$ and $11100 \%$ of the control level, respectively. whereas $7-\mathrm{MC}$ $\mathrm{O}$-demethylase activity was increased merely to $142 \%$, and the ratio of the three $\mathrm{O}$-dealkylase activities was 1.00:11.65:9.76. Likewise, the $\beta-N F$ treatment markedly enhanced 7-EC O-deethylase and 7-PC Odepropylase activities to $1140 \%$ and $7700 \%$ of the control level, respectively, although 7 MC O-demethylase activity was not signifi- cantly affected (125\% of the control level). The ratio of the three $\mathrm{O}$-dealkylase activities was $1.00: 9.87: 7.70$. The isosafrole treatment also enhanced 7-EC O-deethylase and 7-PC O-depropylase activities to $923 \%$ and $6300 \%$ of the contral level, respectively, whereas 7MC O-dementhylase activity was increased merely to $142 \%$, and the ratio of the three 0 dealkylase activities was 1.00:7.06:5.56.

The effects of these three compounds, 3MC, $\beta-N F$ and isosafrole, which induce socalled P-448, were similar to each other; that is, they markedly enhanced 7-EC O-deethylase and 7-PC O-depropylase activities. 


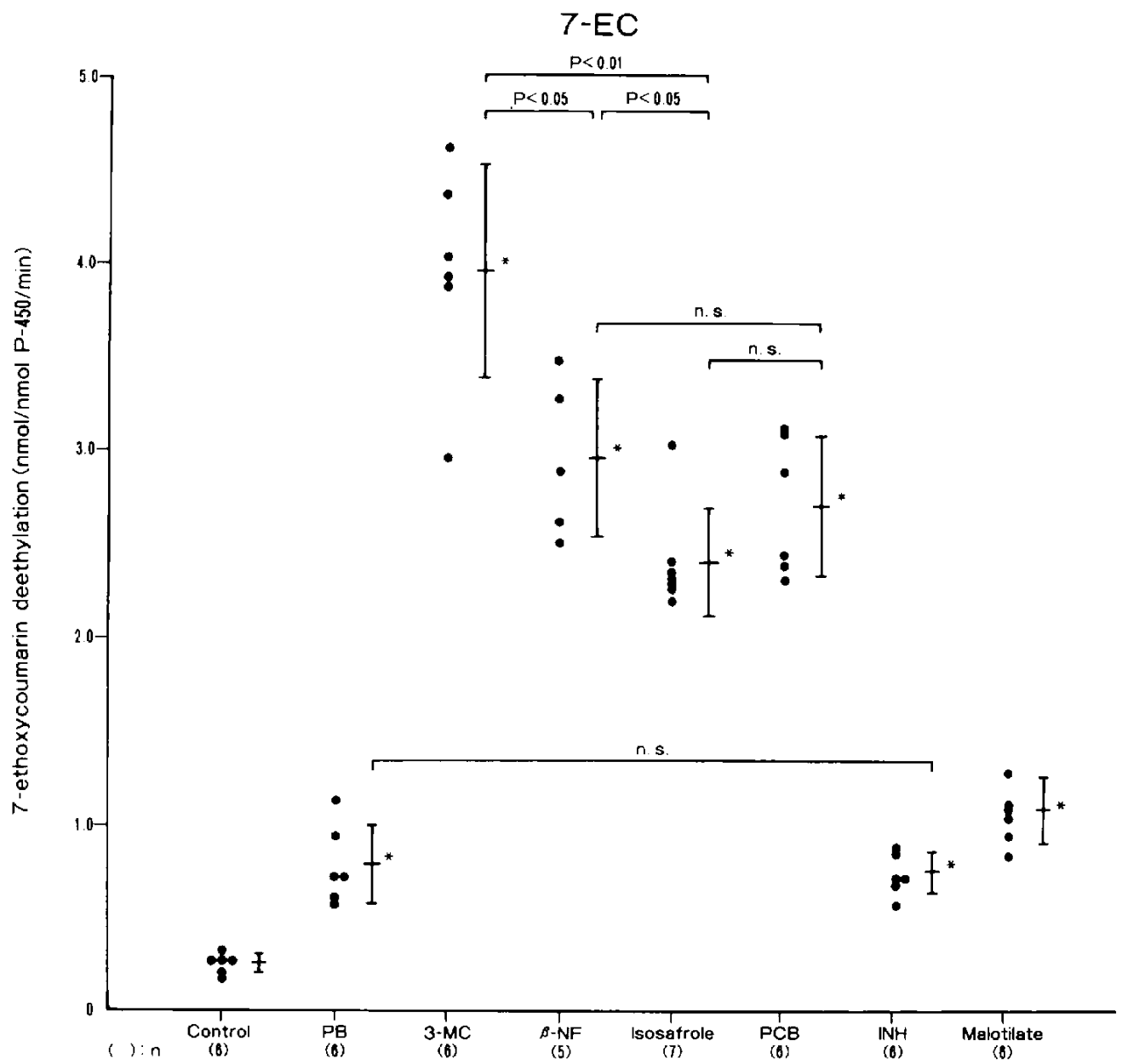

Fig. 2. The effects of phenobarbital (PB), 3-methylcholanthrene (3-MC). $\beta$-naphthoflavone ( $\beta$-NF). isosafrole, polychlorinated biphenyls (PCB), isoniazid (INH) and malotilate on 7 -ethoxycoumarin (7-EC) O-deethylase activity. Each drug was administered as follows: $P B, 100 \mathrm{mg} / \mathrm{kg}$, i.p., for 6 days: $3-\mathrm{MC}$, $40 \mathrm{mg} / \mathrm{kg}$, i.p., for 3 days; $\beta$-NF, $40 \mathrm{mg} / \mathrm{kg}$. i.p., for 3 days; isosafrole, $150 \mathrm{mg} / \mathrm{kg}$, i.p., for 3 days; PCB, $100 \mathrm{mg} / \mathrm{kg}$, i.p. for 3 days; INH, $50 \mathrm{mg} / \mathrm{kg}$, i.p., for 10 days: malotilate, $500 \mathrm{mg} / \mathrm{kg}$. p.o.. for 3 days. Liver microsomes were prepared for the assays $24 \mathrm{hr}$ after the final administration of the drugs. Vertical bars represent the mean \pm S.D. *Significantly different from the control ( $P<0.01)$.

but not 7-MC O-demethylase activity. Concerning 7-MC O-demethylase activity, no significant difference was observed among the 3-MC-. $\beta-N F-$ and isosafrole-treated groups. In contrast, 7-EC O-deethylase and 7-PC O-depropylase activities in these groups were significantly different from each other. so that the ratio of the three $\mathrm{O}$-dealkylase activities was slightly but clearly different from each other.

The $\mathrm{PCB}$ treatment enhanced the $\mathrm{O}$ - dealkylase activities toward 7-MC, 7-EC and 7 -PC to $221 \%, 1040 \%$ and $7230 \%$ of the control level, respectively, and the ratio of the three O-dealkylase activities was 1.00:5.09: 4.09. The 7-MC O-demethylase activity in the PCB-treated group was similar to that in the PB-treated group, and no significant difference was observed between the two groups. In contrast, 7-EC O-deethylase and 7PC O-depropylase activities in the PCBtreated group were similar to those in the $\beta$ - 


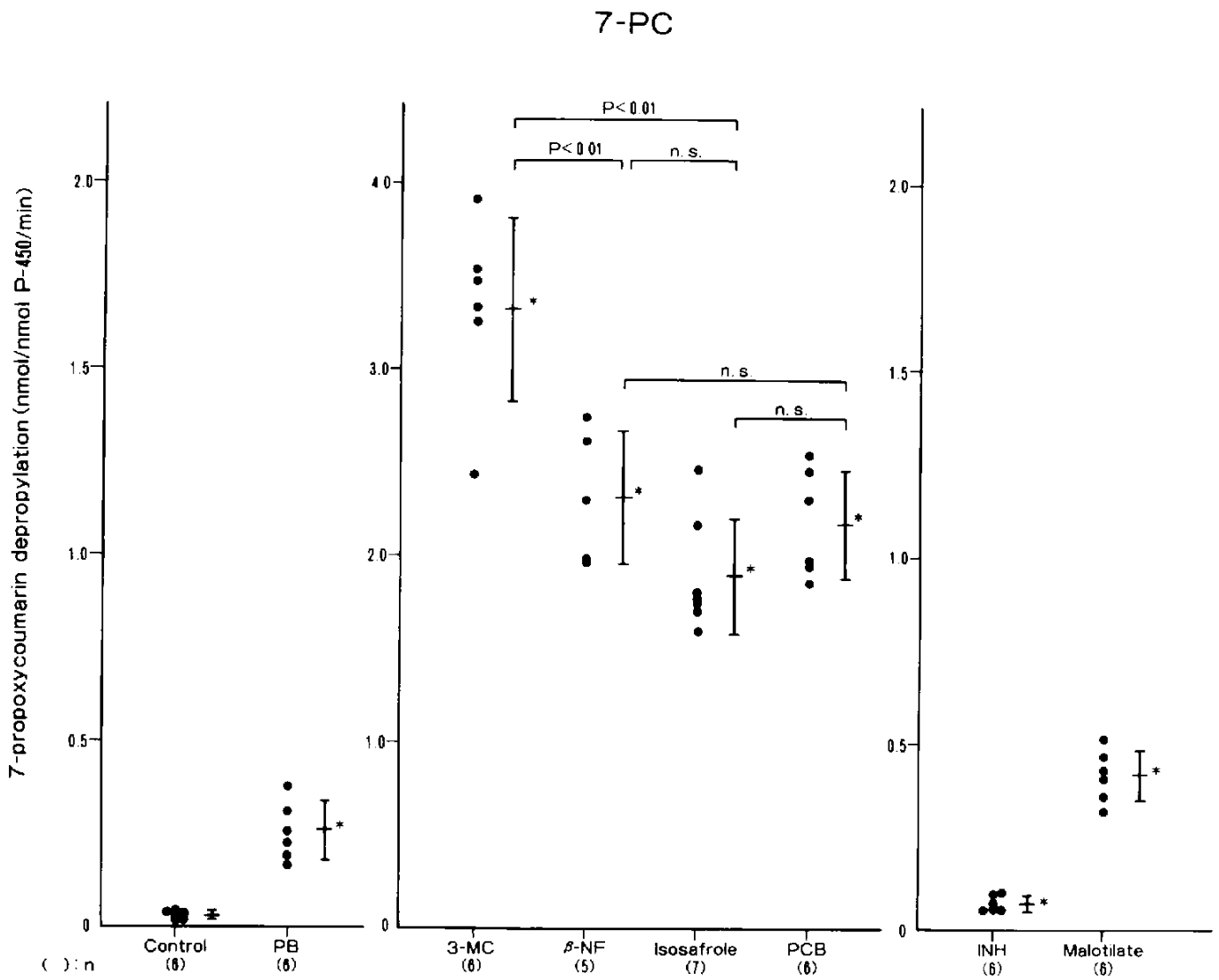

Fig. 3. The effects of phenobarbital (PB). 3-methylcholanthrene (3-MC), $\beta$-naphthoflavone ( $\beta$-NF), isosafrole, polychlorinated biphenyls (PCB), isoniazid (INH) and malotilate on 7 -propoxycoumarin (7PC) O-depropylase activity. Each drug was administered as follows: PB, $100 \mathrm{mg} / \mathrm{kg}$. i.p., for 6 days; $3-M C, 40 \mathrm{mg} / \mathrm{kg}$, i.p., for 3 days; $\beta$-NF, $40 \mathrm{mg} / \mathrm{kg}$. i.p. for 3 days; isosafrole, $150 \mathrm{mg} / \mathrm{kg}$, i.p., for 3 days: PCB, $100 \mathrm{mg} / \mathrm{kg}$, i.p., for 3 days; $1 \mathrm{NH}, 50 \mathrm{mg} / \mathrm{kg}$, i.p., for 10 days; malotilate, $500 \mathrm{mg} / \mathrm{kg}$, p.o., for 3 days. Liver microsomes were prepared for the assays $24 \mathrm{hr}$ after the final administration of the drugs. Vertical bars represent the mean \pm S.D. *Significantly different from the control $(P<0.01)$.

NF- and isosafrole-treated groups, and no significant difference was observed between the PCB- and $\beta$-NF-treated groups and between the PCB- and isosafrole-treated groups.

In the $1 \mathrm{NH}$-treated group, the O-dealkylase activities toward 7-MC, 7-EC and 7-PC were significantly increased to similar extents: that is, $263 \%, 288 \%$ and $233 \%$ of the control level. respectively. The ratio of the three $\mathrm{O}$ dealkylase activities in the $\mid \mathrm{NH}$-treated group was 1.00:1.19:0.11, which was similar to that in the control group. Concerning 7-MC Odemethylase and 7-EC O-deethylase activities, no significant difference was observed between the INH- and PB-treated groups.

On the other hand, the malotilate treatment enhanced the $\mathrm{O}$-dealkylase activities toward 7-MC, 7-EC and 7-PC to $217 \%, 415 \%$ and $1400 \%$ of the control level, respectively. The 7-MC O-demethylase activity in the malotilate-treated group was similar to that in the PB-treated group, and no significant difference was observed between the two groups. However, the ratio of the three $\mathrm{O}$ dealkylase activities in the malotilate-treated group was 1.00:2.08:0.81, which was different from that in any other inducer-treated group examined. 
Table 2. A comparison of the effects of six inducers and malotilate on the O-dealkylase activities toward 7-methoxycoumarin (7-MC), 7-ethoxycoumarin (7-EC) and 7-propoxycoumarin (7-PC)

\begin{tabular}{|c|c|c|c|}
\hline & $\begin{array}{c}\text { 7-MC } \\
\text { O-demethylation }\end{array}$ & $\begin{array}{c}7-E C \\
\text { O-deethylation } \\
(\mathrm{nmol} / \mathrm{nmol} \mathrm{P}-450 / \mathrm{min})\end{array}$ & $\begin{array}{c}\text { 7-PC } \\
\text { O-depropylation }\end{array}$ \\
\hline $\begin{array}{l}\text { Control } \\
\qquad(n=6)\end{array}$ & $\begin{array}{c}0.24 \pm 0.05 \\
(1.00)\end{array}$ & $\begin{array}{c}0.26 \pm 0.05 \\
(1.08)\end{array}$ & $\begin{array}{c}0.030 \pm 0.009 \\
(0.13)\end{array}$ \\
\hline $\begin{array}{l}\text { PB } \\
\qquad(n=6)\end{array}$ & $\begin{array}{c}0.58 \pm 0.11 \\
(1.00)\end{array}$ & $\begin{array}{c}0.79 \pm 0.21 \\
(1.36)\end{array}$ & $\begin{array}{c}0.26 \pm 0.08 \\
(0.45)\end{array}$ \\
\hline $\begin{array}{l}3 \cdot M C \\
\quad(n=6)\end{array}$ & $\begin{array}{c}0.34 \pm 0.05 \\
(1.00)\end{array}$ & $\begin{array}{r}3.96 \pm 0.57 \\
(11.65)\end{array}$ & $\begin{array}{c}3.32 \pm 0.49 \\
(9.76)\end{array}$ \\
\hline $\begin{array}{l}\beta-N F \\
\quad(n=5)\end{array}$ & $\begin{array}{c}0.30 \pm 0.06 \\
(1.00)\end{array}$ & $\begin{array}{c}2.96 \pm 0.42 \\
(9.87)\end{array}$ & $\begin{array}{c}2.31 \pm 0.36 \\
(7.70)\end{array}$ \\
\hline $\begin{array}{l}\text { Isosafrole } \\
\qquad(n=7)\end{array}$ & $\begin{array}{c}0.34 \pm 0.05 \\
(1.00)\end{array}$ & $\begin{array}{c}2.40 \pm 0.29 \\
(7.06)\end{array}$ & $\begin{array}{c}1.89 \pm 0.31 \\
(5.56)\end{array}$ \\
\hline $\begin{array}{l}P C B \\
\qquad(n=6)\end{array}$ & $\begin{array}{c}0.53 \pm 0.07 \\
(1.00)\end{array}$ & $\begin{array}{c}2.70 \pm 0.38 \\
(5.09)\end{array}$ & $\begin{array}{c}2.17 \pm 0.29 \\
(4.09)\end{array}$ \\
\hline $\begin{array}{l}\mathrm{INH} \\
\quad(n=6)\end{array}$ & $\begin{array}{c}0.63 \pm 0.11 \\
(1.00)\end{array}$ & $\begin{array}{c}0.75 \pm 0.11 \\
(1.19)\end{array}$ & $\begin{array}{c}0.070 \pm 0.021 \\
(0.11)\end{array}$ \\
\hline $\begin{array}{c}\text { Malotilate } \\
(n=6)\end{array}$ & $\begin{array}{c}0.52 \pm 0.08 \\
(1.00)\end{array}$ & $\begin{array}{c}1.08 \pm 0.18 \\
(2.08)\end{array}$ & $\begin{array}{c}0.42 \pm 0.07 \\
(0.81)\end{array}$ \\
\hline
\end{tabular}

The drugs administered were as follows: phenobarbital (PB), $100 \mathrm{mg} / \mathrm{kg}$, i.p., for 6 days; 3 -methylcholanthrene ( 3 -MC), $40 \mathrm{mg} / \mathrm{kg}$, i.p., for 3 days: $\beta$-naphthoflavone $(\beta-N F), 40 \mathrm{mg} / \mathrm{kg}$, i.p., for 3 days; isosafrole, $150 \mathrm{mg} / \mathrm{kg}$, i.p., for 3 days; polychlorinated biphenyls (PCB), $100 \mathrm{mg} / \mathrm{kg}$, i.p., for 3 days; isoniazid (INH), $50 \mathrm{mg} / \mathrm{kg}$. i.p., for 10 days; malotilate, $500 \mathrm{mg} / \mathrm{kg}$, p.o., for 3 days. Liver microsomes were prepared for the assays $24 \mathrm{hr}$ after the final administration of the drugs. Each value represents the mean $\pm S . D$.

\section{Discussion}

P-450, which is a key enzyme in the mixedfunction oxidase system in liver microsomes, consists of multiple species; various compounds induce a different form(s) of P-450 $(2,3)$. Imai (3) summarized the relationship between the molecular species of $P-450$ in rats and the compounds which induce them. According to his review. PB mainly induces P-450b,e; 3-MC mainly induces P-450c,d; $\beta-N F$ mainly induces P.450c; isosafrole mainly induces $P-450 d$; PCB mainly induces $\mathrm{P}-450 \mathrm{~b}, \mathrm{c}, \mathrm{d}, \mathrm{e}$; and $\mathrm{INH}$ mainly induces $\mathrm{P}$ $450 j$ (the names of $P-450$ species are based on the nomenclature by Levin et al. (4-9)).

The effects of these six inducers on 7alkoxycoumarin $\mathrm{O}$-dealkylase activities were examined in this study, which confirmed that all of the O-dealkylase activities toward 7MC, 7-EC and 7-PC were stimulated by the $\mathrm{PB}$ treatment; in contrast, the $3-\mathrm{MC}$ and $\beta$ NF treatments markedly enhanced 7-EC Odeethylase and 7-PC O-depropylase activi- ties, but not 7-MC O-demethylase activity, as described by Matsubara et al. (10). The isosafrole treatment also markedly enhanced 7-EC O-deethylase and 7-PC O-depropylase activities, but not 7-MC O-demethylase activity, as reported by Kamataki et al. (12). Socalled P-448-inducing agents, 3 -MC, $\beta$-NF and isosafrole. similarly affected 7-alkoxycoumarin $\mathrm{O}$-dealkylase activities, but the ratios of 7-EC O-deethylase and 7-PC Odepropylase to 7-MC O-demethylase activity in these three inducer-treated groups were slightly but clearly different from each other. These differences might have indicated the slight differences in the molecular forms of P-450 induced by $3-M C, \beta-N F$ and isosafrole, although they all induced socalled P-448(s).

PCB induced P-450b.c.d.e, that is both PBinduced forms (P-450b,e) and the so-called $P-448$ s (P-450c,d). The effect of PCB on 7 alkoxycoumarin $\mathrm{O}$-dealkylase activities was similar to those of both $\mathrm{PB}$ and P-448inducing agents. The 7-MC O-demethylase 
activity in the PCB-treated group was similar to that in the PB-treated group: on the other hand, 7-EC O-deethylase and 7-PC Odepropylase activities were similar to those in the $\beta-N F$ - and isosafrole-treated groups.

The effect of $I N H$, which induced P-450!, on 7-alkoxycoumarin $\mathrm{O}$-dealkylase activities was completely different from those of $P B$. $P-448$-inducing agents and PCB. All of the $\mathrm{O}$-dealkylase activities toward 7-MC, 7-EC and 7-PC were stimulated by the $\mathrm{NHH}$ treatment to similar extents, so that the ratio of the three $\mathrm{O}$-dealkylase activities was similar to the control group.

As described above, the effects of the six inducers examined, each of which induces a different form(s) of P-450. on 7-alkoxycoumarin $\mathrm{O}$-dealkylase activities were different. In particular, the ratio of $7-E C$ Odeethylase and 7-PC O-depropylase to 7-MC $O$-demethylase activity was clearly different among the groups treated with the six inducers, suggesting that the ratio of these three activities were very sensitive in reflecting the molecular form(s) of P-450 induced. Therefore, the measurement of the O-dealkylase activities toward 7-MC, 7-EC and $7-P C$ and the determination of the ratio of these three $\mathrm{O}$-dealkylase activities should be extremely useful for the routine determination of the molecular species of P-450.

On the other hand, the effect of malotilate. which is considered a new type of inducer $(13,14)$, on 7 -alkoxycoumarin 0 -dealkylase activities was clearly different from that of any other inducer examined in these experiments. Therefore, malotilate may have affected the population of $\mathrm{P}-450$ species, and there might be a possibility that malotilate induced a form(s) of P-450 that is different from any of the already known species. Kawata et al. (19) recently demonstrated using reconstituted systems that the stimulatory effect of $b_{5}$ on $\mathrm{p}$-nitroanisole $\mathrm{O}$-demethylase activity and $\mathrm{N}$-demethylase activities toward aminopyrine and benzphetamine in the P-450 preparation from malotilate-treated rats was more conspicuous than that in the preparation from control rats. They suggested that the microsomes of the malotilate-treated rats contained a form(s) of P-450 which required $b_{5}$ for the maximal activities of the demethyl- ation reactions. Their report supports our observations that malotilate might have affected the molecular species of P-450.

The measurement of 7 -alkoxycoumarin $\mathrm{O}$ dealkylase activities has some advantages. First, this method does not require the use of dangerous carcinogenic compounds nor organic solvents, as Matsubara et al. $(10,20)$ also pointed out concerning their own methods; benzo(a)pyrene hydroxylation. for example, needs organic solvents for the assay and produces carcinogenic metabolites, although it is very specific for $P-448$. Secondly, an individual difference was scarcely observed concerning the ratio of $7-\mathrm{EC} \mathrm{O}$ deethylase and 7-PC O-depropylase to 7-MC $\mathrm{O}$-demethylase activity, although the absolute value of these activities in each rat varied to some extent. For example, in the six rats treated with PCB, the ratios of 7-EC Odeethylase to $7-\mathrm{MC} \mathrm{O}$-demethylase activity were $4.72,5.03,5.48,4.95,5.02$ and 5.40 ; the ratios of $7-\mathrm{PC} \mathrm{O}$-depropylase to $7-\mathrm{MC}$ O-demethylase activity were $3.84,4.01,4.42$. 4.02, 4.03 and 4.27; and the ratio of the three O-dealkylase activities in this group was

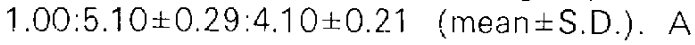
similar tendency was observed in the other groups (data not shown). Third, as Matsubara et al. $(20,21)$ already reported, these 0 dealkylase activities could be measured using not only liver microsomes but also whole liver homogenates. Indeed, this method is very sensitive, so that these $\mathrm{O}$-dealkylase activities can be measured using at least $10 \mathrm{mg}$ of a liver specimen obtained by human liver biopsy (data not shown). Therefore, this method is clinically applicable for the determination of the drug-metabolizing activity in the human liver. Further studies along this line are in progress in our laboratory.

\section{References}

1 Kato, R.: Possible role of P-450 in the oxidation of drugs in liver microsomes. J. Biochem. 59, 574-583 (1966)

2 Imai, Y. and Sato, R.: Multiplicity of hepatic microsomal cytochrome P-450: Molecular species and substrate specificity. Taisha 19, 1723-1735 (1982) (in Japanese)

3 Imai, Y.: Molecular multiplicity and nomenclature of hepatic microsomal cytochrome P-450. SaiboKogaku 6, 98-108 (1987) (in Japanese) 
4 Ryan, D.E., Thomas, P.E., Korzeniowski, D. and Levin, W.: Separation and characterization of highly purified forms of liver microsomal cytochrome P-450 from rats treated with polychlorinated biphenyls, phenobarbital, and 3methylcholanthrene. J. Biol. Chem. 254, 13651374 (1979)

5 Ryan, D.E., Thomas, P.E. and Levin, W.: Hepatic microsomal cytochrome $\mathrm{P}-450$ from rats treated with isosafrole: Purification and characterization of four enzymic forms. J. Biol. Chem. 255, 79417955 (1980)

6 Ryan, D.E., Thomas, P.E. and Levin, W.: Purification and characterization of a minor form of hepatic microsomal cytochrome $\mathrm{P}-450$ from rats treated with polychlorinated biphenyls. Arch. Biochem. Biophys. 216, 272-288 (1982)

7 Ryan, D.E., lida, S., Wood, A.W., Thomas, P.E., Lieber, C.S. and Levin, W.: Characterization of three highly purified cytochromes P-450 from hepatic microsomes of adult male rats. J. Biol. Chem. 259, 1239-1250 (1984)

8 Haniu, M., Ryan, D.E., lida, S., Lieber, C.S., Levin, $W$. and Shively, J.E.: $\mathrm{NH}_{2}$-terminal sequence analyses of four rat hepatic microsomal cytochromes P-450. Arch. Biachem. Biophys. 235, 304-311 (1984)

9 Ryan, D.E., Ramanathan, L., lida, S., Thomas, P.E., Haniu, M., Shively, J.E., Lieber, C.S. and Levin, W.: Characterization of a major form of rat hepatic microsomal cytochrome $\mathrm{P}-450$ induced by isoniazid. J. Biol. Chem. 260, 6385-6393 (1985)

10 Matsubara, T., Yoshihara, E., Iwata, T., Tochino, $Y$. and Hachino, $Y$.: Biotransformation of coumarin derivatives (1): 7-alkoxycoumarin $\mathrm{O}$ dealkylase in liver microsomes. Japan. J. Pharmacol. 32, 9-21 (1982)

11 Kasahara, A., Hayashi, N., Sato, N., Meren, H., Saito, M., Yoshihara, H., Fusamoto, H., Kamada, T. and Abe, H.: Study on drug-metabolizing enzyme system by coumarin derivatives. Acta Hepatol. Japon. 23, 873-878 (1982) (Abs. in English)

12 Kamataki, T., Ando, M., Yamazoe, Y., Ishii, K. and Kato, R.: Sex difference in the O-dealkylation activity of 7 -hydroxycoumarin $\mathrm{O}$-alkyl derivatives in liver microsomes of rats. Biochem. Pharmacol.
29, 1015-1022 (1980)

13 Katoh, M., Kitada, M., Satoh, T., Kitagawa, H., Sugimoto, T. and Kasai, T.: Further studies on the in vivo effect of diisopropyl 1.3-dithiol-2ylidenemalonate (NKK-105) on the liver microsomal drug oxidation system in rats. Biochem. Pharmacol. 30, 2759-2765 (1981)

14 Okuno, H., Murase, T., Nakanishi, S., Shiozaki, $Y$. and Sameshima, Y.: Effect of malotilate (diisopropyl 1.3-dithiol-2-ylidenemalonate) on drug metabolizing activity in rat liver microsomes. Japan. J. Pharmacol. 44, 303-310 (1987)

15 Omura, T. and Sato, R.: The carbon monoxidebinding pigment of liver microsomes. J. Biol. Chem. 239, 2370-2385 (1964)

16 Omura, T. and Takesue, S.: A new method for simultaneous purification of cytochrome $b_{5}$ and NADPH-cytochrome $c$ reductase from rat liver microsomes. J. Biochem. 67, 249-257 (1970)

17 Lowry, O.H., Rosebrough, N.J., Farr, A.L. and Randall, R.J.: Protein measurement with the Folin phenol reagent. J. Biol. Chem. 193, 265275 (1951)

18 Ullrich, $V$. and Weber, P.: The O-dealkylation of 7-ethoxycoumarin by liver microsomes: A direct fluorometric test. Hoppe Seylers Z. Physiol. Chem. 353, 1171-1177 (1972)

19 Kawata, S., Sugiyama, T., Seki, K., Tarui, S., Okamoto, M. and Yamano, T.: Stimulatory effect of cytochrome $b_{5}$ induced by p-nitroanisole and diisopropyl 1,3-dithiol-2-ylideriemalonate on rat liver microsomal drug hydroxylations. J. Biochem. 92, 305-313 (1982)

20 Matsubara, T., Otsubo, S., Yoshihara, E. and Touchi, A.: Biotransformation of coumarin derivatives (2): Oxidative metabolism of 7 aikoxycoumarin by microsomal enzymes and a simple assay procedure for 7 -alkoxycoumarin 0 dealkylase. Japan. J. Pharmacol. 33, 41-56 (1983)

21 Matsubara, T., Yamada, N., Mitomi, T., Yokoyama, S., Fukiishi, Y., Hasegawa, Y. and Nishimura, H.: Cytochrome P-450-dependent monooxygenase activities in prenatal and postnatal human livers: Comparison of human liver 7-alkoxycoumarin $\mathrm{O}$-dealkylases with rat liver enzymes. Japan. J. Pharmacol. 40, 389-398 (1986) 